\title{
Use of an Ethanol Bio-Refinery Product as a Soy Bean Alternative in Diets for Fast-Growing Meat Production Species: A Circular Economy Approach
}

\author{
Emily Burton ${ }^{1, *}$, Dawn Scholey ${ }^{1}$, Ashraf Alkhtib ${ }^{1} \mathbb{D}$ and Peter Williams ${ }^{2}$ \\ 1 School of Animal, Rural and Environmental Sciences, Brackenhurst Campus, Nottingham Trent University, \\ Southwell NG25 0QF, UK; dawn.scholey@ntu.ac.uk (D.S.); ashraf.alkhtib@ntu.ac.uk (A.A.) \\ 2 Fluid Quip Technologies, LLC, A Division of Green Plains Inc., Cedar Rapids, IA 52402, USA; \\ PWilliams@fluidquiptechnologies.com \\ * Correspondence: Emily.burton@ntu.ac.uk
}

check for updates

Citation: Burton, E.; Scholey, D.; Alkhtib, A.; Williams, P. Use of an Ethanol Bio-Refinery Product as a Soy Bean Alternative in Diets for Fast-Growing Meat Production Species: A Circular Economy Approach. Sustainability 2021, 13, 11019. https://doi.org/10.3390/ su131911019

Academic Editor: Michael S. Carolan

Received: 2 September 2021

Accepted: 28 September 2021

Published: 4 October 2021

Publisher's Note: MDPI stays neutral with regard to jurisdictional claims in published maps and institutional affiliations.

Copyright: (c) 2021 by the authors. Licensee MDPI, Basel, Switzerland. This article is an open access article distributed under the terms and conditions of the Creative Commons Attribution (CC BY) license (https:/ / creativecommons.org/licenses/by/ $4.0 /)$.

\begin{abstract}
The recent conceptual pivot from bioethanol production to ethanol biorefining has led to development of protein derived by fractionating the non-ethanol streams post fermentation within the plant. The aim of this study was to identify the effect of replacing dietary soy with corn-fermented protein (CFP) on performance of fast-growing meat species and the impact on the carbon footprint associated with the feed for each species. The study contains trials on 3 species, broiler, turkey and salmon. In trial one, 324 broiler chicks were allocated randomly to 36 pens distributed into 3 dietary treatments; control ( $0 \%$ CFP), 5\% CFP and 10\% CFP; for 35 days. In trial 2 , 150 turkey poults were allocated to 3 treatments: control (0 CFP), 4\% CFP and 8\% CFP for 35 days. In trial 3, 525 Atlantic Salmon (starting weight $304 \mathrm{~g} \pm 10.7 \mathrm{~g}$ ) were raised in 15 saltwater tanks for 84 days with 5 treatments, control (0\% CFP), 5\% CFP, 10\% CFP, 15\% CFP and 20\% CFP. Growth response, nutrient utilisation and carbon footprint were assessed in each trial. Replacement of soy with CFP showed limited differences in growth response and nutrient utilization but replacing soy bean meal with CFP at rate of $5 \%, 8 \%$ and $10 \%$ in broiler, turkey and salmon diets, respectively resulted in a $14 \%$ decrease in carbon footprint of diet manufacturing. This investigation shows coupling bioethanol production with poultry and salmon production represents a highly effective circular economy contributing to multiple UN Sustainable Development Goals.
\end{abstract}

Keywords: sustainable development; food security; biorefining; salmon; poultry; net zero

\section{Introduction}

Poultry and fish are both increasing in popularity as protein sources in human diets. Fish consumption has increased by 122\% between 1990 and 2018 [1] with an over 500\% rise in aquaculture production globally over the same timescale. Salmon production is estimated to reach 2.7 million tonnes (MT) by 2021, compared to 0.8 MT in 2000 [2]. Similarly, poultry meat production is also increasing year on year and is predicted to have reached $137 \mathrm{MT}$ in 2020 [1]. This rapid increase in the scale of meat production inevitably creates a conflicting global role for poultry and fish production: in rapidly increasing their contribution to UN Sustainable Development Goal (SDG) 2 (Zero hunger) and SDG 3 (Good health and wellbeing), the negative implications for SDG 12 (Responsible consumption and production) and SDG 13 (Climate action) are concurrently increased through increased resource use and pollution, respectively. Development of circular economies is an effective way to reduce the livestock and poultry pollution, improve the utilization efficiency of resources [3], and to balance economic development and environmental protection [3]. It is well recognised that the potential for extensive environmental impact from poultry production is substantial if a linear model is followed [4] and the key to sustainable development in animal production is conversion of potential waste and pollutants into 
resources [4]: negative externalities may be transformed into positives ones by identifying potential beneficiaries of waste streams [3].

Historically, circular economy models involving poultry production have focussed on the waste (or, more appropriately, co-product) streams associated with meat or egg production. The scale and speed of bird growth on a modern poultry farms means that a single farm may produce more than 700 tonnes of manure each year. This volume far exceeds the volume that may be safely applied as fertiliser to surrounding arable land, leading to harmful levels of $\mathrm{N}$ and $\mathrm{P}$ levels in soil if application to land is continued [5] or, if not managed properly, un-needed manure can be dangerous to the health of local waterways and the people who depend on them [5]. The greatest focus of circular economy models involving poultry production has been on converting the litter (mix of manure and bedding) into energy via anaerobic digestion, combustion, pyrolysis and gasification [5]. Waste management is now attracting increasing cooperation between multi-field stakeholders (including governments) to promote circular economy approaches [5], for example through generation of innovative bio-based functional products from feather meal [5] and egg shells [5] and fish processing waste [5]. While the outputs from fish and poultry production are increasingly incorporated into circular economies, the main input, feed, has moved away from a circular approach where by-products from other food production sectors were used to a high natural resource approach where soya beans are grown specifically for inclusion in animal feed. In order for meat production to develop sustainably, feed producers must revert to their traditional of using co-products from other industries.

Soy is one of the most internationally traded agricultural commodities, and is principally used globally as the protein component of animal feed [6]. Brazil and the United States are jointly the world's leading soy producers and exporters, [7]. While the land use change associated with Unite States soy production occurred more than 25 years ago and so incurs no penalties in current greenhouse gas (GHG) emission assessments, expansion of soy production in Brazil is associated with deforestation [8]. The major role of Brazilian deforestation to GHG emissions (Maciel et al., 2016) is now raising concerns among consumers, leading traders and governments to take measures to prevent deforestation [9]. The carbon footprint (CF) of Brazilian soy used in animal feed depends not only on deforestation, but also the GHG emissions associated with transport to the importing country. The required transportation distance for soy used in European countries adds to the CF associated with soy use in European animal feed.

Meat for human consumption is derived from two types of animal: ruminant animals (primarily cattle and sheep) and non-ruminants (primarily fish, pigs and poultry). The ability of ruminants to digest fibre as an energy source and to utilise non-protein nitrogen to meet their amino acid requirements means that ruminant animals such as beef cattle are readily able to consume fibrous products that are not suitable for direct human consumption but their comparatively slow growth and methane gas outputs give a high carbon tariff to beef. In contrast, the high growth rates and extremely efficient feed conversion rate to usable meat of salmon and poultry give them a low carbon footprint but render them extremely sensitive to fluctuations in the quality of feed provided and the density of protein and energy in the feed, which limits the inclusion of many co-products. Each year, more than 30 MT of soybean meal is imported into the EU for inclusion in animal feed due to its high protein content, balance of amino acids and low levels of residual antinutritional factors [7]. Poultry as a whole account for most soy use in the EU [10], but production of soy beans in Europe is limited. Soy has a low yield and long growing season in the European climate and soil, so production cannot compete with the more efficient growth in countries such as Brazil [11]. Soy use often does not fit sustainability objectives [12] particularly as widespread deforestation is common in soy production in many countries.

In order to reduce the use of soy in poultry and fish feed, there is a need to consider novel and alternative proteins associated with lower carbon footprint (CF). Use of some conventional proteins have been limited in the EU, either due to lack of supply [13] or due to EU wide bans [14]. Alongside the mounting pressures to reduce levels of soy 
used in animal feed, legislatures such as The Renewable Fuel Standard in the USA and The Renewable Transport Fuel Obligation in the UK have driven massive increases in bioethanol production from cereal (first generation bioethanol). In 2011, the estimated global production was around 113 billion litres [15]. Production of bioethanol is a exogenous enzyme and fermentation-based technology using Saccharomyces cerevisiae yeast to produce ethanol and a residual mash co-product known as 'whole stillage' which is subsequently decanted into a fibrous wet portion and a liquid component with only around $60-85 \mathrm{~g} / \mathrm{kg}$ dry matter [16], 'thin stillage' that contains the majority of the yeast protein and soluble components. In traditional ethanol fermentation systems, the thin stillage is evaporated into a syrup, remixed with the wet grain and dried to form Distiller's Dried Grains with Solubles (DDGS). The evaporative drying of the co-product is an energydemanding, expensive necessity in order to remove all the "waste" material not required for the production of ethanol from the distillery which, if not removed, would congest the primary process of ethanol production.

DDGS is successfully used in ruminant feed [17] but the high fibre content decreases feed intake and limits nutrient utilization in fast growing species such as pigs, salmon, turkey and broiler (meat-type) chicken [18]. Therefore, the biorefining process associated with bioethanol production has been recently adapted to develop high protein, low fibre biorefinery co-products more suitable for non-ruminant meat species than DDGS [19]. The aim of this study is to assess the nutritional viability of partially replacement of SBM with corn-fermented protein (CFP) in the feed of fast growing meat species and to determine the impact of SBM replacement with CFP on the carbon footprint associated with the feed for each species.

\section{Material and Methods}

\subsection{Study Design}

Three animal growth experiments were conducted to evaluate the impact of replacing soy in salmon, turkey and broiler chickens. Institutional and national guidelines for the care and use of animals were followed and all experimental procedures involving animals were approved by the local ethical review committees. For each growth experiments, diets were formulated to meet the need of the age and strain of species used, with partial replacement of high $(>44 \%)$ protein soy bean meal (SBM) by a high $(>50 \%)$ protein biorefinery co-product (Corn-Fermented Protein from a Maximized Stillage Co-products ${ }^{\mathrm{TM}}$ process, Fluid Quip Technologies, Cedar Rapids, IA, USA) as summarized in Table 1.

Table 1. Replacement levels of soy bean meal with CFP in animal trials.

\begin{tabular}{ccccc}
\hline Species & Treatment & SBM (\%) & CFP (\%) & \% SBM Reduction \\
\hline \multirow{3}{*}{ Turkeys } & control & 47.3 & 0 & 0 \\
& $4 \%$ CFP & 44.6 & 4 & 5.7 \\
& $8 \%$ CFP & 41.9 & 8 & 11.4 \\
\hline \multirow{3}{*}{ Broilers } & control & 34.2 & 0 & 0 \\
& $5 \%$ CFP & 28.6 & 5 & 16.4 \\
& $10 \%$ CFP & 22.9 & 10 & 33 \\
\hline \multirow{5}{*}{ Salmon } & control & 13.2 & 0 & 0 \\
& 5\% CFP & 11.5 & 5 & 25.9 \\
& $10 \%$ CFP & 9.8 & 10 & 37.9 \\
& $15 \%$ CFP & 8.2 & 15 & 50.8 \\
\hline
\end{tabular}

\subsection{Broiler Study}

Male, Ross 308 broilers $(n=324)$ were obtained from a commercial hatchery at day of hatch. Chicks were weighed individually and allocated to $0.64 \mathrm{~m}^{2}$ floor pens in groups of 9 birds per pen. Pens contained clean wood shavings as bedding and two nipple drinkers per pen. There were three dietary treatments with CFP inclusions of 0,4 and $8 \%$ (see 
Table 1 and Appendix A for more information), and these were each randomly allocated to 12 pens by block. Feed was available from $50 \mathrm{~cm}$ troughs in each pen ad libitum. The room was maintained at $31{ }^{\circ} \mathrm{C}$ and reduced based on Ross guidelines and bird behaviour to reach approximately $21^{\circ} \mathrm{C}$ by D21. The lighting was increased from $23 \mathrm{~h}$ on D1 to $18 \mathrm{~h}$ by D6, and the $6 \mathrm{~h}$ of dark were maintained throughout the rest of the study. Diets were commercially formulated using a wheat, soy bean meal base and were produced by a commercial manufacturing facility (Target Feeds Ltd., Shropshire, UK). Diets were fed in two phases, starter crumb (D0-21) and grower pellet (D21-42), and all diets contained $0.5 \% \mathrm{TiO}_{2}$ as an inert marker for digestibility measures. Nitrogen content of the diets was determined using a combustion analyser (Dumatherm N Pro, Gerhardt Analytical Systems, Germany) then multiplied by 6.25 to derive crude protein content. Dry matter content and ether extractable fat content of diets were analyzed according to [20] (methods 930.15 and 945.16, respectively) was analysed by bomb calorimetry with sucrose as a standard [21]. Diet analysis is available in Appendix A, Table A1.

Birds and feed were weighed weekly on a pen basis to calculate bodyweight gain, feed intake and feed conversion ratio (FCR). On D42, two birds per pen were euthanized by cervical dislocation and butchered by a trained operative to assess carcass yield. Breast, thigh and drumstick (excluding skin) were collected and pooled to give an incomplete estimate of carcass meat yield. Excreta was collected per pen on D42, with a minimum of $10 \mathrm{~g}$ collected per pen, and dried in a forced air oven at $105^{\circ} \mathrm{C}$ until constant weight. Dried, ground excreta and diets were analysed for titanium dioxide content by the spectrophotometric method described by [22]. Excreta was also analysed for nitrogen content as previously described. Nitrogen retention was calculated using the following equation:

$$
\mathrm{N} \text { per g diet }-\mathrm{N} \text { per g Excreta } \times\left(\text { Diet } \mathrm{TiO}_{2} / \text { Excreta } \mathrm{TiO}_{2}\right)
$$

Statistical analysis was carried out using R [23]. Data outside 2 standard deviations from the mean for each variable were considered as outliers. Data of the study were analysed according to the following model:

$$
Y(i j)=\mu+\operatorname{Diet}(i)+\operatorname{Block}(j)+\varepsilon(i j)
$$

where $Y$ is the response variable, $\mu$ is the overall mean, Diet is the effect of the experimental diet and $\varepsilon$ is the residual. The pen was used as an experimental unit. Means were separated using Tukey's test at $p \leq 0.05$.

\subsection{Turkey Study}

Male, BUT6 turkey poults $(n=150)$ were collected on day of hatch and allocated in groups of five to 10 pens per treatment. Pens were $0.64 \mathrm{~m}^{2}$ and contained two water nipples and clean wood shavings as bedding. The room was maintained at $32{ }^{\circ} \mathrm{C}$ from D0 and the temperature was reduced daily to reach $21^{\circ} \mathrm{C}$ by D21. Lighting was $23 \mathrm{~h}$ of light a day until D2, decreasing by $1 \mathrm{~h}$ a day to reach $8 \mathrm{~h}$ of darkness, which was then maintained throughout the study. Diets were formulated by a commercial nutritionist to be matched for protein, amino acids and energy (formulations and analysis in Appendix A). Treatments contained 0, 4 and $8 \%$ of CFP as detailed in Table 1 (see Appendix A, Table A2 for diet details) and all diets contained $0.5 \% \mathrm{TiO}_{2}$ as an indigestible marker. Each treatment was randomly allocated by block to 10 pens and was feed and water were available ad libitum throughout the study. Diets were provided as starter, sieved crumb (D0-21) and grower, short pellet (D21-42) and manufactured by a commercial mill (Target Feeds, Ltd., Shropshire, UK). Diets were analysed as previously described.

Poults and feed were weighed weekly by pen to calculate bodyweight gain, feed intake and FCR. On D42 3 birds per pen were culled by cervical dislocation and ileal digesta collected from the region between Meckel's Diverticulum and the ileal cecal junction. Ileal digesta was pooled per pen and freeze dried and ground before analysis. 
Diets and digesta were analysed for nitrogen content and titanium dioxide marker to assess ileal nitrogen digestibility using the following equation

$$
\mathrm{N} \text { per g diet }-\mathrm{N} \text { per g Digesta } \times\left(\text { Diet } \mathrm{TiO}_{2} / \text { Digesta } \mathrm{TiO}_{2}\right)
$$

Statistical analysis was carried out using SPSS v.24. After KS testing to confirm normality, data were analysed using one way ANOVA to investigate the effect of dietary treatment on FCR, feed intake (per bird) and individual bodyweight gain for each weigh period of the study, and cumulatively. Where appropriate, Bonferroni post hoc testing was used to elucidate differences between diets/treatments.

\subsection{Salmon Study}

Atlantic Salmon ( $n=525$; starting weight $304 \mathrm{~g} \pm 10.7 \mathrm{~g}$ ) were raised in 15 saltwater (25 ppt) tanks with 35 fish per tank for 84 days. Tanks were maintained in a recirculating aquaculture system using $750 \mathrm{~L}$ tanks and temperatures maintained at $14.2^{\circ} \mathrm{C}\left( \pm 0.6{ }^{\circ} \mathrm{C}\right)$ with greater than $90 \%$ oxygen saturation. A control diet was formulated to meet the needs of Atlantic salmon [24] and four further diets were formulated to contain graded levels of CFP; $5,10,15$ and 20\%. Diets were manufactured and extruded via a twin-screw cooling extruder and vacuum coated in the oil component of the diet (see Table 1 and Appendix A, Table A3). Each diet was fed to three tanks of fish. Salmon were fed by hand to satiety three times a day.

Fish were weighed on D0, 28, 56 and 84 of the study, with 5 fish per tank used to provide a mean fish weight. Five fish per tank were euthanized on D84 for whole body protein composition via the AOAC method (990.03). These results were used to calculate the rate of protein deposition using the following equation [25]:

$$
D_{j}=\frac{F_{j}-I_{j}}{\sum_{i=1}^{n}\left(T_{i} \times t_{i}\right)}
$$

where $D_{j}$ is deposition rate $\left[\mathrm{mg}\left({ }^{\circ} \mathrm{C} \bullet \mathrm{d}\right)-1\right]$ of nutrient $j, F_{j}$ and $I_{j}$ are final and initial whole-body mass of nutrient $j(\mathrm{mg})$ at the end and the beginning of the 84-day period, respectively, $n$ stands for the day number covering the period from $F_{j}$ to $I_{j}, T_{i}\left({ }^{\circ} \mathrm{C}\right)$ is mean daily water temperature for day $T_{i}$, the product of which results in units of degree-days.

The results were analysed using one-way ANOVA and Tukey's multiple comparison test with GraphPad Prism version 8.1.2 for Windows. Statistical differences were considered significant at $p<0.05$.

\subsection{Carbon Footprint Calculation}

Global Food LCA Institute (GFLI) database (version 28-Dec-2018) was used to calculate the carbon footprint of the experimental feed. The carbon footprint of feeds was calculated using ReCiPe 2016 midpoint $(\mathrm{H})$ assessment method with "economic" method of allocation. The GLFI database does not contain the footprint of high protein, ethanol bio-refinery product. Thus, the carbon footprint of high protein, ethanol bio-refinery product was obtained from Tallentire et al. (2018). The carbon footprint $\left(\mathrm{kg} \mathrm{CO}_{2} \mathrm{e} / \mathrm{kg}\right.$ feed) was normalized for $1 \mathrm{~kg}$ of live weigh growth of Turkey and Salmon and $1 \mathrm{~kg}$ of meat yield of broilers.

\section{Results}

\subsection{Broiler Study}

Table 2 summarizes the performance of the broiler study and the nitrogen retention measured in the birds at D42. Feed intake increased with increasing levels of CFP in the diets, with intake of $10 \%$ CFP-fed birds being significantly higher than the control. FCR was also significantly increased for the $10 \%$ CFP diet. Nitrogen retention was significantly improved for the 5\% CFP diet over both the control and the 10\% diet. 
Table 2. Bird weight (BW), feed intake (FI), feed conversion ratio (FCR) and Nitrogen retention for broilers fed graded levels of Corn-Fermented Protein (CFP).

\begin{tabular}{cccccc}
\hline Parameter & Control & $\mathbf{5 \%}$ CFP & $\mathbf{1 0 \%}$ CFP & SEM & $p$ Value \\
\hline BW /bird D0 $(\mathrm{g})$ & 45 & 45 & 44 & 0.2 & 0.086 \\
BW/bird D42 $(\mathrm{g})$ & 3360 & 3439 & 3339 & 32.7 & 0.144 \\
FI/bird D0-42 $(\mathrm{g})$ & $4878^{\mathrm{b}}$ & $5042^{\mathrm{ab}}$ & $5151^{\mathrm{a}}$ & 61.8 & 0.028 \\
FCR D0-42 & $1.47^{\mathrm{a}}$ & $1.49^{\mathrm{a}}$ & $1.57^{\mathrm{b}}$ & 0.02 & 0.005 \\
N retention $(\%)^{*}$ & $29.4^{\mathrm{b}}$ & $30.4^{\mathrm{a}}$ & $28.7^{\mathrm{b}}$ & 0.27 & 0.002 \\
\hline
\end{tabular}

SEM; standard error of the mean. Superscript letters denote significant differences within a row. ${ }^{*}$ excreta nitrogen retention.

Table 3 shows the calculated carbon emissions per $\mathrm{kg}$ of bird growth, and also per $\mathrm{kg}$ of meat production (based on carcass yield of breast, thigh and drum only). It can be seen that all three GHG calculations show a reduction in $\mathrm{CO}_{2}$ emissions with increasing dietary content of CFP.

Table 3. Greenhouse gas emissions (GHG; calculated) on a per bird, per kg growth and per kg meat basis for broilers fed graded levels of corn-fermented protein (CFP).

\begin{tabular}{cccc}
\hline Parameter & Control & $\mathbf{5 \%}$ CFP & $\mathbf{1 0 \%}$ CFP \\
\hline GHG $\left(\mathrm{kg} \mathrm{CO}_{2} \mathrm{e} /\right.$ bird $)$ & 8.22 & 7.49 & 6.62 \\
Meat yield $(\mathrm{kg})$ & 1.41 & 1.49 & 1.45 \\
Weight gain $(\mathrm{kg} /$ bird $)$ & 3.32 & 3.39 & 3.3 \\
GHG $\left(\mathrm{kg} \mathrm{CO}_{2} \mathrm{e} / \mathrm{kg}\right.$ growth $)$ & 2.48 & 2.21 & 2.01 \\
GHG $\left(\mathrm{kg} \mathrm{CO}_{2}\right.$ e/kg meat) & 5.85 & 5.03 & 4.57 \\
\hline
\end{tabular}

\subsection{Turkey Study}

The performance of the turkey poults at D42 is shown in Table 4 . Bodyweights at D42 increased numerically with CFP inclusion, but there were no significant differences in any performance measure over the six-week trial period. Nitrogen retention was significantly increased at $10 \%$ dietary inclusion of CFP over the control, soy-based diet.

Table 4. Performance of turkey poults fed graded levels of corn-fermented protein (CFP).

\begin{tabular}{cccccc}
\hline Parameter & Control & $\mathbf{4 \%}$ CFP & $\mathbf{8 \% ~ C F P ~}$ & SEM & $p$ Value \\
\hline BW /bird D0 $(\mathrm{g})$ & 66 & 66 & 66 & 1 & 0.962 \\
BW/bird D42 $(\mathrm{g})$ & 2328 & 2423 & 2518 & 52.1 & 0.122 \\
FI/bird D0-42 $(\mathrm{g})$ & 3741 & 3850 & 3743 & 77.3 & 0.363 \\
FCR d0-42 & 1.66 & 1.64 & 1.61 & 0.028 & 0.797 \\
N retention $(\%)$ & $18.3^{\mathrm{b}}$ & $21.0^{\mathrm{ab}}$ & $21.8^{\mathrm{a}}$ & 0.98 & 0.001 \\
\hline
\end{tabular}

BW: body weight; FI: feed intake; FCR: feed conversion ratio; N: nitrogen; SEM: standard error of the mean Superscript letters denote significant differences within a row.

Table 5 shows the calculated GHG emissions of the birds fed graded levels of CornFermented Protein (CFP) on a per bird and per kg growth basis. Both measures show a reduction in $\mathrm{CO}_{2}$ emissions with increased CFP inclusion.

Table 5. Greenhouse gas (GHG) emissions for turkey poults fed graded levels of Corn-Fermented Protein (CFP).

\begin{tabular}{cccc}
\hline Parameter & Control & CFP 4\% & CFP 8\% \\
\hline GHG (kg CO 2 e/bird) & 8.96 & 8.88 & 8.34 \\
Weight gain (kg/bird) & 2.26 & 2.36 & 2.45 \\
GHG (kg CO 2 e/kg growth) & 3.96 & 3.77 & 3.40 \\
\hline
\end{tabular}




\subsection{Salmon Study}

The fish performance measures and the protein retention for the trial period (84 days) is shown in Table 6. Final salmon weights were significantly higher for the $10 \%$ CFP inclusion diet compared with the $20 \%$ inclusion diet ( $752.1 \mathrm{~g}$ vs. $663.7 \mathrm{~g}$, respectively). Feed intake was also highest for the 10\% CFP diet and the control diet compared with the $20 \%$ CFP diet. There were no significant differences in FCR or protein retention during the duration of this study.

Table 6. Performance and protein deposition in salmon fed graded levels of Corn-Fermented Protein (CFP) over an 84-day trial period.

\begin{tabular}{cccccccc}
\hline Parameter & Control & $\mathbf{5 \%}$ CFP & $\mathbf{1 0 \%}$ CFP & $\mathbf{1 5 \%}$ CFP & 20\% CFP & SEM & $p$ Value \\
\hline Initial BW (g) D0 & 295 & 301.9 & 305.7 & 304.7 & 305 & 5.28 & 0.858 \\
Final BW (g) D84 & $720.0^{\mathrm{ab}}$ & $701.1^{\mathrm{ab}}$ & $752.1^{\mathrm{a}}$ & $690.8^{\mathrm{ab}}$ & $663.7^{\mathrm{b}}$ & 15.96 & 0.034 \\
FI/fish D0-84 (g) & $411.9^{\mathrm{a}}$ & $370.5^{\mathrm{ab}}$ & $414.4^{\mathrm{a}}$ & $377.8^{\mathrm{ab}}$ & $348.3^{\mathrm{b}}$ & 11.74 & 0.016 \\
FCR D0-84 & 0.98 & 0.93 & 0.93 & 0.97 & 0.97 & 0.014 & 0.288 \\
Protein deposition (\%) & 19.8 & 23.1 & 23.0 & 22.1 & 26.0 & 1.46 & 0.181 \\
\hline
\end{tabular}

SEM: standard error of the mean. Superscript letters denote significant differences within a row.

Table 7 shows the calculated GHG emissions and $\mathrm{CO}_{2}$ output for the salmon study. $\mathrm{CO}_{2}$ output is reported on a per $\mathrm{kg}$ feed basis and also per $\mathrm{kg}$ of fish growth. Increasing inclusion of CFP reduces GHG emissions in a linear fashion.

Table 7. Greenhouse gas emissions (GHG; calculated) for salmon fed graded levels of Distiller's high protein (CFP).

\begin{tabular}{cccccc}
\hline Parameter & Control & $\mathbf{5 \%}$ CFP & $\mathbf{1 0 \%}$ CFP & $\mathbf{1 5 \%}$ CFP & 20\% CFP \\
\hline GHG (kg feed) & 1.64 & 1.55 & 1.47 & 1.39 & 1.3 \\
Weight gain (kg) & 0.425 & 0.399 & 0.446 & 0.386 & 0.359 \\
GHG (kg CO 2 e/kg growth) & 1.59 & 1.44 & 1.37 & 1.36 & 1.27 \\
\hline
\end{tabular}

\section{Discussion}

Previous studies theoretically modelling LCA have suggested that a CFP type product increases nitrogen excretion associated negative environmental impacts [26], but this study showed that nitrogen utilization was significantly improved with CFP for both poultry studies studied and not affected in salmon. Therefore, although the CFP has higher total protein nitrogen than SBM, its improved digestibility mitigates the additional feed nitrogen and reduces excretion to a similar level to SBM. Beyond the positive environmental impact associated with this improved nutrient utilization, further quantifiable effects are incurred earlier in the meat production process; associated with production of the individual feed material. Agricultural land use (ALU) associated with feed material production substantially contributes to $\mathrm{CF}$, so maintaining low ALU values is a key focus in low carbon meat production. In the case of CFP, the ALU comes almost entirely from the production of the cereal crop [26]. However, with multiple product streams deriving from the fermentation process, this ALU tariff is spread across a number of co-products including as corn oil and bioethanol. Therefore, the calculated CF of diets including CFP are substantially reduced compared to diets relying on SBM as the main dietary protein source.

Use of soy as livestock feed outside the Americas incur a high $\mathrm{CO}_{2}$ cost relating to the long distance of transportation. In addition, South American soy production is associated with high level of deforestation, resulting in particularly high ALU tariffs derived from the additional land use change. Accordingly, decreasing the dependency on soy in livestock nutrition would reduce the negative consequences of soy production and transportation on the environment due to the large penalties associated with land use change. CFP is currently produced at 500 thousand tonnes per annum from six bioethanol plants in the USA, which will increase to an estimated 1 million tonnes a year by the end of 2023. CFP is a co-product with high protein content which is produced from bioethanol generation. Accordingly, it is 
expected to be a low-GHG replacement of soy in livestock nutrition. Furthermore, it is more cost-effective source of nutrients for livestock compared to conventional feedstuffs [27].

The results of the current study show $\mathrm{N}$ retention of broilers fed diets containing $5 \%$ CFP in place of SBM, and 8\% CFP in turkey diets was higher than the control; which conflicts with previous studies on traditional bioethanol co-product: DDGS. Ref. [28,29] reported that increased manure production and manure $\mathrm{N}$ excretion was produced by broilers fed high-protein corn distillers dried grains. This negative effect may be due to the increase in dietary fibre and reduction in protein digestibility resulting from heat damage associated with DDGS production [30]. However, the replacement of soy by CFP in the current study did not introduce sufficient fibre or heat-damaged protein to negatively impact on broiler performance or nitrogen retention. Furthermore, the high digestibility of CFP reduces $\mathrm{N}$ excretion in comparison to wholly SBM-based diets. This improvement in $\mathrm{N}$ retention of broilers fed 5\% CFP would decrease the NH3 emission from broiler production, creating added value from 5\% CFP inclusion beyond the quantified parameters reported in the current study. Interestingly, 10\% dietary inclusion of CFP improved nitrogen retention of broilers, but also increased feed intake without a concurrent improvement in weight gain, so deleteriously effecting feed conversion ratio and therefore negatively impacting the economic viability of including $10 \%$ CFP in broiler diets. However, a $10 \%$ dietary inclusion of CFP provides a $19 \%$ reduction in $\mathrm{CO}_{2}$ output compared with the control diet on a basis of per $\mathrm{kg}$ growth, and a $22 \%$ reduction in $\mathrm{CO}_{2}$ emissions on the basis of $\mathrm{kg}$ of meat produced. This reduction is $11 \%$ (per $\mathrm{kg}$ meat) and $14 \%$ (per $\mathrm{kg}$ meat) for the $5 \%$ inclusion of CFP. Turkeys may be fed diets including to 8\% CFP in place of SBM with no effect on performance but a reduction in GHG emissions of $14 \%$ compared to turkeys fed the control diet. Distillers dried grains with solubles were included in broilers (up to 12\%) and Turkeys (up to $8 \%$ diets) without negative consequences on growth performance [30]. Similarly to the poultry studies, the salmon study showed no improvement in growth related to dietary SBM replacement with FP, and, as with the broilers, the highest CFP level diet led to a small, negative effect on growth. This lack of improved growth response in salmon is surprising as previous studies show DDGS may totally replaces fish meal in fish diets when fishmeal is included at a level of $12 \%$ of the diet [31]. The DDGS was used as a protein source in rainbow trout diet without negative effect on digestibility and growth [30]. It has also been reported that DDGS can be used at levels up to $90 \%$ of winter diets for channel catfish without amino acids supplementation [32,33]. In alignment with the poultry trials, inclusion of $10 \%$ CFP in salmon diets leads to a reduction in $\mathrm{CO}_{2}$ cost of one $\mathrm{kg}$ growth of almost $14 \%$ over the control diet.

In all three species assessed, the impacts on growth performance were limited but the positive impacts of including CFP in place of soy on the CF of each species diet were substantial. This initial evidence that partial CFP replacement of dietary soy reduces the carbon footprint of meat production justifies further in vivo studies directly assessing carbon cost of meat from fish and poultry fed CFP-containing diets as predictive modelling approaches (Tallentyre et al., 2018) provide conflicting results.

In all three species assessed, the impacts on growth performance were limited but the positive impacts of including CFP in place of soy on the CF of each species diet were substantial. This initial evidence that partial CFP replacement of dietary soy reduces the carbon footprint of meat production justifies further in vivo studies directly assessing carbon cost of meat from fish and poultry fed CFP-containing diets as predictive modelling approaches (Tallentyre et al., 2018) provide conflicting results. Inclusion of CFP in broiler, turkey and salmon diets at a rate of $5 \%, 8 \%$ and $10 \%$, respectively improved nitrogen retention while decreasing GHG emissions. This indicates partial replacement of soy with CFP in the diets of fast-growing meat species would reduce the environmental impact of meat production without impacting on growth performance.

Successful circular economies rely on precise alignment of needs between producers and users. Cereal-based bioethanol plants have historically produced a secondary product of low and inconsistent nutrient value that has limited attraction as an animal feed mate- 
rial. The expansion of cereal-based bioethanol production raised initial concerns that the concurrent increased supply of the traditional co-product (DDGS) would exceed feed use potential [34]. However, the reframing of bioethanol production into biorefining, where multiple product streams are empirically scrutinized and modelled for optimum plant design [35], has revolutionized the sustainability of cereal-based bioethanol plants. The new engineering and plant design focus has been on optimizing the generation of high-quality protein from the bioethanol plants [36]. The multiple-species evaluation of CFP reported here shows that the biorefinery approach has created a protein product aligned to the needs of very high-volume users: salmon and poultry meat producers. The economic impact on the bioethanol plants pivoting to a biorefinery approach with multiple high value streams was particularly apparent as demand for transport fuel decreased during the early phase COVID-19 pandemic [37]. The environmental impact of partially replacing soy with a biorefinery product (CFP) in the diet of salmon and poultry has been clearly demonstrated in the reported studies. This shows that the development of circular economies is not only an effective way to reduce the livestock and poultry pollution, but may also be used to improve the utilization efficiency of resources and support environmental protection, thereby allowing meat production to simultaneously supporting a number of UN SDGs without concurrent detriment to others.

\section{Conclusions}

Inclusion of CFP in broiler, turkey and salmon diets at a rate of $5 \%, 8 \%$ and $10 \%$, respectively improved nitrogen retention while decreasing GHG emissions. This indicates partial replacement of soy with CFP in the diets of fast-growing meat species would reduce the environmental impact of meat production without impacting on growth performance. Corn-fermented protein (CFP) presents a nutritionally viable option for partial replacement of soy in fish and poultry feed. The replacement of $10 \%$ of dietary soy with CFP is associated with a $19 \%$ and $14 \%$ reduction in $\mathrm{CO}_{2}$ production associated with poultry and salmon production, respectively. Coupling bioethanol production with poultry and salmon production represents a highly effective circular economy.

Author Contributions: Conceptualization, P.W. and E.B.; methodology, P.W., D.S. and A.A., investigation, E.B., P.W. and D.S.; data curation, D.S. and A.A.; manuscript preparation, E.B., A.A. and D.S. All authors have read and agreed to the published version of the manuscript.

Funding: The authors would like to acknowledge the financial support of Fluid Quip Technologies, LLC to cover the cost of completing the three animal experiments.

Institutional Review Board Statement: Not applicable.

Informed Consent Statement: Not applicable.

Data Availability Statement: The datasets generated during the current study are available from the corresponding author on reasonable request.

Acknowledgments: The authors would like to thank the research teams involved at Nottingham Trent University and The Center for Aquaculture Technologies Canada.

Conflicts of Interest: Peter Williams is employed as a consultant by Fluid Quip Technologies, LLC and contributed to the design of the studies but not the interpretation of the findings, which was undertaken by the NTU authors who declare no conflict of interest. 


\section{Appendix A}

Table A1. Turkey diets formulation, starter and grower phases.

\begin{tabular}{|c|c|c|c|c|c|c|}
\hline \multirow[b]{2}{*}{ Ingredient (g/kg) } & \multicolumn{3}{|c|}{ Starter } & \multicolumn{3}{|c|}{ Grower } \\
\hline & Control & $4 \%$ DHP & $8 \%$ DHP & Control & $4 \%$ DHP & $8 \%$ DHP \\
\hline Corn fermented protein (CFP) & 0 & 40 & 80 & 0 & 40 & 80 \\
\hline Dicalcium P $18 \%$ & 41.3 & 41.1 & 41 & 37.5 & 37.4 & 37.3 \\
\hline DL Methionine & 3.8 & 3.7 & 3.6 & 3.3 & 3.1 & 3 \\
\hline Full fat Soya & 20 & 20 & 20 & 20 & 20 & 20 \\
\hline High protein sunflower meal & 30 & 30 & 30 & 30 & 30 & 30 \\
\hline Limestone & 8.2 & 8.5 & 8.8 & 7.8 & 8.1 & 8.3 \\
\hline Lysine mono $\mathrm{HCl}$ & 4 & 4.1 & 4.2 & 3.5 & 3.6 & 3.7 \\
\hline Salt & 1.6 & 1.5 & 1.5 & 1.7 & 1.7 & 1.6 \\
\hline Sodium Bicarbonate & 3.1 & 3.1 & 3.2 & 2.6 & 2.6 & 2.7 \\
\hline Hipro soya & 473 & 446.2 & 419.4 & 404.6 & 377.8 & 351 \\
\hline Soya oil & 32.7 & 30.7 & 28.6 & 32.9 & 30.8 & 28.8 \\
\hline Vit/Min premix * & 4 & 4 & 4 & 4 & 4 & 4 \\
\hline Threonine & 0.6 & 0.4 & 0.2 & 0.6 & 0.3 & 0.1 \\
\hline Maize & 377.1 & 366 & 355 & 451 & 439.9 & 428.9 \\
\hline \multicolumn{7}{|l|}{ Total calculated $\mathrm{g} / \mathrm{kg}$} \\
\hline Dry matter & 889.9 & 891.9 & 894 & 889.1 & 891.2 & 893.3 \\
\hline Ash & 73.1 & 73.4 & 73.7 & 66.7 & 67 & 67.3 \\
\hline Protein & 276.4 & 282.4 & 288.4 & 249.3 & 255.4 & 261.4 \\
\hline EE Fat & 58.5 & 56.3 & 54.1 & 60.1 & 57.9 & 55.7 \\
\hline Gross energy (MJ / kg) & 11.9 & 11.9 & 11.9 & 12.2 & 12.2 & 12.2 \\
\hline Calcium & 14 & 14 & 14 & 12.8 & 12.8 & 12.8 \\
\hline Av Phosphorous & 7 & 7 & 7 & 6.4 & 6.4 & 6.4 \\
\hline Cysteine & 4.3 & 4.4 & 4.6 & 3.9 & 4.1 & 4.2 \\
\hline Methionine & 7.8 & 7.9 & 8.1 & 6.9 & 7.0 & 7.2 \\
\hline Lysine & 18.8 & 18.9 & 19.0 & 16.6 & 16.7 & 16.8 \\
\hline Threonine & 11.1 & 11.1 & 11.2 & 10.0 & 10.0 & 10.1 \\
\hline Valine & 12.5 & 12.9 & 13.2 & 11.2 & 11.6 & 12.0 \\
\hline Isoleucine & 11.7 & 11.9 & 12.1 & 10.4 & 10.7 & 10.9 \\
\hline Leucine & 21.7 & 22.8 & 24.0 & 19.9 & 21.1 & 22.2 \\
\hline Tyrosine & 8.3 & 7.8 & 7.3 & 7.1 & 6.6 & 6.1 \\
\hline Phenylalanine & 11.2 & 11.5 & 11.9 & 9.5 & 9.9 & 10.3 \\
\hline Arginine & 18.8 & 18.8 & 18.8 & 16.8 & 16.8 & 16.8 \\
\hline
\end{tabular}

All diets contained $0.6 \mathrm{~g} / \mathrm{kg}$ coccidiostat; * Premix content (volume/kg diet): Mn 100 mg, Zn 88 mg, Fe 20 mg, Cu 10 mg, I 1 mg, Mb $0.48 \mathrm{mg}$, Se $0.2 \mathrm{mg}$, Retinol $13.5 \mathrm{mg}$, Cholecalciferol, $3 \mathrm{mg}$, Tocopherol $25 \mathrm{mg}$, Menadione $5.0 \mathrm{mg}$, Thiamine $3 \mathrm{mg}$, Riboflavin $10.0 \mathrm{mg}$, Pantothenic acid $15 \mathrm{mg}$, Pyroxidine $3.0 \mathrm{mg}$, Niacin $60 \mathrm{mg}$, Cobalamin $30 \mu \mathrm{g}$, Folic acid $1.5 \mathrm{mg}$, Biotin $125 \mathrm{mg}$.

Table A2. Broiler diet formulations.

\begin{tabular}{|c|c|c|c|c|c|c|}
\hline \multirow[b]{2}{*}{$\%$ in Diet } & \multicolumn{3}{|c|}{ Starter } & \multicolumn{3}{|c|}{ Grower } \\
\hline & Control & $5 \%$ DHP & $10 \%$ DHP & Control & $5 \%$ DHP & $10 \%$ DHP \\
\hline Wheat & 60.28 & 61.41 & 62.16 & 67.58 & 68.68 & 69.84 \\
\hline Hipro soya & 34.24 & 28.55 & 22.85 & 25.58 & 19.99 & 14.28 \\
\hline Soya oil & 1.95 & 1.36 & 1 & 4.1 & 3.52 & 2.93 \\
\hline Limestone & 1.12 & 1.17 & 1.32 & 0.89 & 0.94 & 0.99 \\
\hline Mono cal P & 0.94 & 0.9 & 0.86 & 0.55 & 0.5 & 0.46 \\
\hline Salt & 0.25 & 0.19 & 0.15 & 0.25 & 0.23 & 0.19 \\
\hline Sodium Bicarbonate & 0.15 & 0.22 & 0.27 & 0.15 & 0.17 & 0.22 \\
\hline Lysine HCL & 0.25 & 0.35 & 0.45 & 0.2 & 0.28 & 0.37 \\
\hline DL Methionine & 0.29 & 0.28 & 0.26 & 0.22 & 0.19 & 0.17 \\
\hline L Arginine & 0 & 0.2 & 0.11 & 0 & 0 & 0.07 \\
\hline
\end{tabular}


Table A2. Cont.

\begin{tabular}{|c|c|c|c|c|c|c|}
\hline \multirow[b]{2}{*}{$\%$ in Diet } & \multicolumn{3}{|c|}{ Starter } & \multicolumn{3}{|c|}{ Grower } \\
\hline & Control & $5 \%$ DHP & $10 \%$ DHP & Control & $5 \%$ DHP & $10 \%$ DHP \\
\hline L Threonine & 0.12 & 0.13 & 0.14 & 0.07 & 0.07 & 0.07 \\
\hline Valine & & & 0.005 & & & \\
\hline Phytase/Econase & 0.02 & 0.02 & 0.02 & 0.02 & 0.2 & 0.2 \\
\hline Premix * & 0.4 & 0.4 & 0.4 & 0.4 & 0.4 & 0.4 \\
\hline Corn fermented protein (CFP) & 0 & 5 & 10 & 0 & 5 & 10 \\
\hline \multicolumn{7}{|c|}{ Nutrient content (\% unless stated) } \\
\hline Oil A (Ether Extract) & 4.13 & 3.99 & 3.16 & 5.98 & 5.18 & 4.95 \\
\hline Calcium & 0.72 & 0.99 & 0.93 & 0.67 & 0.64 & 0.64 \\
\hline Copper (mg/kg) & 56 & 48 & 30 & 20 & 16 & 18 \\
\hline Iron $(\mathrm{mg} / \mathrm{kg})$ & 563 & 532 & 265 & 113 & 92 & 106 \\
\hline Magnesium & 0.16 & 0.16 & 0.16 & 0.11 & 0.12 & 0.12 \\
\hline Manganese (mg/kg) & 128 & 148 & 137 & 117 & 116 & 117 \\
\hline Phosphorus & 0.56 & 0.59 & 0.57 & 0.42 & 0.42 & 0.43 \\
\hline Potassium & 0.95 & 0.93 & 0.89 & 0.71 & 0.7 & 0.65 \\
\hline Sodium & 0.15 & 0.21 & 0.18 & 0.13 & 0.14 & 0.15 \\
\hline Zinc (mg/kg) & 135 & 149 & 137 & 121 & 106 & 117 \\
\hline Crude Protein & 21.7 & 21.9 & 22.1 & 16.8 & 18.6 & 19.1 \\
\hline Crude Fibre & 2.3 & 2.4 & 2.2 & 2.2 & 2.3 & 2.4 \\
\hline Dry Matter & 88.4 & 88.9 & 88.4 & 88 & 88.1 & 88.7 \\
\hline Ash & 5.4 & 6.1 & 5.4 & 5 & 4.9 & 4.8 \\
\hline Total Oil (Oil B) & 4.84 & 4.74 & 3.87 & & & \\
\hline Cystine & 0.3 & 0.33 & 0.34 & 0.29 & 0.3 & 0.33 \\
\hline Aspartic & 1.96 & 1.83 & 1.73 & 1.49 & 1.48 & 1.49 \\
\hline Methionine & 0.53 & 0.62 & 0.57 & 0.45 & 0.49 & 0.49 \\
\hline Threonine & 0.86 & 0.88 & 0.86 & 0.67 & 0.71 & 0.75 \\
\hline Serine & 1.01 & 0.99 & 0.98 & 0.83 & 0.87 & 0.93 \\
\hline Glutamic & 4.47 & 4.37 & 4.44 & 3.82 & 3.99 & 4.23 \\
\hline Glycine & 0.91 & 0.9 & 0.86 & 0.69 & 0.72 & 0.76 \\
\hline Alanine & 0.88 & 0.93 & 0.97 & 0.68 & 0.76 & 0.88 \\
\hline Valine & 0.89 & 0.95 & 0.96 & 0.75 & 0.8 & 0.86 \\
\hline Iso-Leucine & 0.86 & 0.85 & 0.83 & 0.67 & 0.71 & 0.74 \\
\hline Leucine & 1.52 & 1.58 & 1.69 & 1.22 & 1.39 & 1.6 \\
\hline Tyrosine & 0.48 & 0.53 & 0.51 & 0.35 & 0.43 & 0.46 \\
\hline Phenylalanine & 1.01 & 0.99 & 1.01 & 0.81 & 0.85 & 0.91 \\
\hline Histidine & 0.51 & 0.51 & 0.52 & 0.41 & 0.44 & 0.48 \\
\hline Lysine & 1.24 & 1.3 & 1.27 & 0.92 & 1.01 & 1.08 \\
\hline Arginine & 1.29 & 1.24 & 1.26 & 1.01 & 1.18 & 1.17 \\
\hline Proline & 1.36 & 1.54 & 1.51 & 1.14 & 1.29 & 1.38 \\
\hline
\end{tabular}

* Premix content (volume/kg diet): Mn 100 mg, Zn 88 mg, Fe 20 mg, Cu 10 mg, I 1 mg, Mb 0.48 mg, Se 0.2 mg, Retinol 13.5 mg, Cholecalciferol, $3 \mathrm{mg}$, Tocopherol $25 \mathrm{mg}$, Menadione $5.0 \mathrm{mg}$, Thiamine $3 \mathrm{mg}$, Riboflavin $10.0 \mathrm{mg}$, Pantothenic acid $15 \mathrm{mg}$, Pyroxidine $3.0 \mathrm{mg}$, Niacin $60 \mathrm{mg}$, Cobalamin $30 \mu \mathrm{g}$, Folic acid $1.5 \mathrm{mg}$, Biotin $125 \mathrm{mg}$.

Table A3. Salmon study diet formulation.

\begin{tabular}{|c|c|c|c|c|c|}
\hline Raw Material (\%) & Control & $5 \%$ DHP & $10 \%$ DHP & $15 \%$ DHP & $20 \%$ DHP \\
\hline Poultry by product meal & 20 & 19.118 & 18.237 & 17.355 & 16.473 \\
\hline Corn fermented protein (CFP) & 0 & 5 & 10 & 15 & 20 \\
\hline Fish oil herring & 19.516 & 19.516 & 19.516 & 19.516 & 19.516 \\
\hline Fish meal herring & 15 & 15 & 15 & 15 & 15 \\
\hline Soy protein concentrate & 13.196 & 11.522 & 9.848 & 8.174 & 6.5 \\
\hline Wheat Flour & 12.002 & 10.803 & 9.604 & 8.404 & 7.205 \\
\hline Corn protein concentrate & 8.662 & 7.47 & 6.278 & 5.085 & 3.893 \\
\hline Wheat gluten meal & 5 & 5 & 5 & 5 & 5 \\
\hline Rapeseed oil & 2.602 & 2.603 & 2.604 & 2.605 & 2.606 \\
\hline Monocalcium phosphate $(21 \% \mathrm{P})$ & 2.176 & 2.099 & 2.022 & 1.944 & 1.867 \\
\hline L-Lysine & 0.714 & 0.742 & 0.77 & 0.798 & 0.826 \\
\hline
\end{tabular}


Table A3. Cont.

\begin{tabular}{|c|c|c|c|c|c|}
\hline Raw Material (\%) & Control & $5 \%$ DHP & $10 \%$ DHP & $15 \%$ DHP & $20 \%$ DHP \\
\hline Vitamin and Mineral Premix * & 0.5 & 0.5 & 0.5 & 0.5 & 0.5 \\
\hline Vitamin C (Stay-C) & 0.3 & 0.3 & 0.3 & 0.3 & 0.3 \\
\hline L-Histidine & 0.249 & 0.242 & 0.235 & 0.228 & 0.221 \\
\hline Carophyll Pink & 0.05 & 0.05 & 0.05 & 0.05 & 0.05 \\
\hline DL Methionine & 0.033 & 0.036 & 0.038 & 0.041 & 0.043 \\
\hline \multicolumn{6}{|l|}{ Nutrient content $(\%)$} \\
\hline Dry matter & 92.124 & 92.205 & 92.286 & 92.366 & 92.447 \\
\hline Crude protein & 44 & 44 & 44 & 44 & 44 \\
\hline Crude lipid & 28 & 28 & 28 & 28 & 28 \\
\hline Gross energy (MJ/kg) & 23.93 & 23.464 & 22.997 & 22.531 & 22.064 \\
\hline Crude fibre & 0.754 & 0.676 & 0.599 & 0.521 & 0.443 \\
\hline Ash & 5.891 & 5.818 & 5.744 & 5.671 & 5.597 \\
\hline Lysine & 3.338 & 3.344 & 3.349 & 3.355 & 3.36 \\
\hline Digestible lysine & 3 & 3 & 3 & 3 & 3 \\
\hline Methionine & 1.216 & 1.219 & 1.222 & 1.225 & 1.228 \\
\hline Digestible methionine & 1.095 & 1.095 & 1.095 & 1.095 & 1.095 \\
\hline Arginine & 2.633 & 2.593 & 2.553 & 2.512 & 2.472 \\
\hline Histidine & 1.2 & 1.2 & 1.2 & 1.2 & 1.2 \\
\hline Isoleucine & 1.908 & 1.899 & 1.889 & 1.88 & 1.87 \\
\hline Leucine & 3.676 & 3.692 & 3.709 & 3.725 & 3.741 \\
\hline Phenylalanine & 1.84 & 1.838 & 1.835 & 1.833 & 1.83 \\
\hline EPA & 1.232 & 1.232 & 1.232 & 1.232 & 1.232 \\
\hline DHA & 0.8 & 0.8 & 0.8 & 0.8 & 0.8 \\
\hline Phosphorus & 0.979 & 0.989 & 0.999 & 1.008 & 1.018 \\
\hline Digestible phosphorus & 0.682 & 0.682 & 0.682 & 0.682 & 0.682 \\
\hline Calcium & 0.768 & 0.747 & 0.726 & 0.704 & 0.683 \\
\hline Astaxanthin & 0.005 & 0.005 & 0.005 & 0.005 & 0.005 \\
\hline
\end{tabular}

* Premix content (volume/kg diet): Mn 100 mg, Zn 88 mg, Fe 20 mg, Cu 10 mg, I 1 mg, Mb 0.48 mg, Se 0.2 mg, Retinol 13.5 mg, Cholecalciferol, $3 \mathrm{mg}$, Tocopherol $25 \mathrm{mg}$, Menadione $5.0 \mathrm{mg}$, Thiamine $3 \mathrm{mg}$, Riboflavin $10.0 \mathrm{mg}$, Pantothenic acid $15 \mathrm{mg}$, Pyroxidine $3.0 \mathrm{mg}$, Niacin $60 \mathrm{mg}$, Cobalamin $30 \mu \mathrm{g}$, Folic acid $1.5 \mathrm{mg}$, Biotin $125 \mathrm{mg}$.

\section{References}

1. FAO The State of World Fisheries and Aquaculture 2020 The State of World Fisheries and Aquaculture 2020. Available online: http:/ / www.fao.org/3/ca9229en/ca9229en.pdf (accessed on 18 August 2020).

2. Statistica Global Production of Atlantic Salmon 2000-2021. Available online: https://www.statista.com/statistics/1179062/ global-atlantic-salmon-production/ (accessed on 20 August 2021).

3. Yunan, X.; Weixin, L.; Yujie, Y.; Hui, W. Evolutionary game for the stakeholders in livestock pollution control based on circular economy. J. Clean. Prod. 2021, 282, 125403. [CrossRef]

4. Bilitewski, B. Circular Economy: Balancing Development and Environmental Protection. In Proceedings of the 2nd International Conference on Asian-European Environmental Technology and Knowledge Transfer, Hefei, China, 5 June 2008.

5. Millette, S.; Eiríkur Hull, C.; Williams, E. Business incubators as effective tools for driving circular economy. J. Clean. Prod. 2020, 266, 121999. [CrossRef]

6. COMTRADE Resource Trade.Earth. Available online: https:// resourcetrade.earth/ (accessed on 20 August 2021).

7. Heuzé, V.; Tran, G.; Kaushik, S. Soybean Meal. Available online: https:/ /www.feedipedia.org/node/674 (accessed on 26 August 2021).

8. Zalles, V.; Hansen, M.C.; Potapov, P.V.; Stehman, S.V.; Tyukavina, A.; Pickens, A.; Song, X.-P.; Adusei, B.; Okpa, C.; Aguilar, R.; et al. Near doubling of Brazil's intensive row crop area since 2000. Proc. Natl. Acad. Sci. USA 2019, 116, 428-435. [CrossRef]

9. Nepstad, D.; McGrath, D.; Stickler, C.; Alencar, A.; Azevedo, A.; Swette, B.; Bezerra, T.; DiGiano, M.; Shimada, J.; Seroa da Motta, R.; et al. Slowing Amazon deforestation through public policy and interventions in beef and soy supply chains. Science 2014, 344, 1118-1123. [CrossRef]

10. Van Gelder, J.; Kammeraat, K.; Kroes, H. Soy Consumption for Feed and Fuel in the European Union (Miscellaneous). Available online: https:/ / www.osti.gov/etdeweb/biblio/21234002 (accessed on 20 August 2021).

11. van Krimpen, M.; Bikker, P.; Ivan der Meer, I.; van der Peet-Schwering, C.; Vereijken, J. Cultivation, Processing and Nutritional Aspects for Pigs and Poultry of European Protein Sources as Alternatives for Imported Soybean Products; Wageningen UR Livestock Research: Wageningen, The Netherlands, 2013.

12. Kebreab, E.; Liedke, A.; Caro, D.; Deimling, S.; Binder, M.; Finkbeiner, M. Environmental impact of using specialty feed ingredients in swine and poultry production: A life cycle assessment. J. Anim. Sci. 2016, 94, 2664-2681. [CrossRef] [PubMed] 
13. Brookes, G. The EU Animal Feed Sector: Protein Ingredient Use and Implications of the Ban on Use of Meat and Bonemeal. Available online: https:/ / www.pgeconomics.co.uk/pdf/mbmbanimpactjan2001.pdf (accessed on 26 August 2021).

14. European Commission Council. Regulation (EC) 999/2001 of the 21 May 2001 Laying Down Rules for the Prevention Control and Eradication of Certain Transmissible Spongiform Encephalopathies. Available online: https://eur-lex.europa.eu/legal-content/ EN/ALL/?uri=CELEX\%3A32001R0999 (accessed on 26 August 2021).

15. OECD/FAO Agricultural Outlook 2017-2026. Special Focus: Southeast Asia. Available online: http://aii.caas.net.cn/ AgriOutlook/pdf/3-B3.StefaniaVannuccini_OECD-FAOAgriculturalOutlook2013-2022_ChinaFishOutlook.pdf (accessed on 26 August 2021).

16. Balat, M.; Balat, H.; Öz, C. Progress in bioethanol processing. Prog. Energy Combust. Sci. 2008, 34, 551-573. [CrossRef]

17. Yang, Y.; Heijungs, R.; Brandão, M. Hybrid life cycle assessment (LCA) does not necessarily yield more accurate results than process-based LCA. J. Clean. Prod. 2017, 150, 237-242. [CrossRef]

18. Youssef, I.M.I.; Westfahl, C.; Sünder, A.; Liebert, F.; Kamphues, J. Evaluation of dried distillers' grains with solubles (DDGS) as a protein source for broilers. Arch. Anim. Nutr. 2008, 62, 404-414. [CrossRef]

19. Burton, E.J.; Scholey, D.V.; Williams, P.E.V. Use of cereal crops for food and fuel-Characterization of a novel bioethanol coproduct for use inmeat poultry diets. Food Energy Secur. 2013, 2, 197-206. [CrossRef]

20. AOAC. Official Methods of Analysis, 17th ed.; AOAC International: Gaithersburg, MD, USA, 2003.

21. Robbins, D.; Firman, J. Evaluation of the Metabolizable Energy of Poultry By-Product Meal for Chickens and Turkeys by Various Methods. Int. J. Poult. Sci. 2006, 5, 753-758. [CrossRef]

22. Short, F.J.; Gorton, P.; Wiseman, J.; Boorman, K.N. Determination of titanium dioxide added as an inert marker in chicken digestibility studies. Anim. Feed Sci. Technol. 1996, 59, 215-221. [CrossRef]

23. R Core Team. R: A Language and Environment for Statistical Computing; R Foundation for Statistical Computing: Vienna, Austria, 2017.

24. NRC. Nutrient Requirements of Fish and Shrimp; National Academies Press: Washington, DC, USA, 2011; ISBN 978-0-309-16338-5.

25. Dumas, A.; de Lange, C.F.M.; France, J.; Bureau, D.P. Quantitative description of body composition and rates of nutrient deposition in rainbow trout (Oncorhynchus mykiss). Aquaculture 2007, 273, 165-181. [CrossRef]

26. Tallentire, C.W.; Mackenzie, S.G.; Kyriazakis, I. Can novel ingredients replace soybeans and reduce the environmental burdens of European livestock systems in the future? J. Clean. Prod. 2018, 187, 338-347. [CrossRef]

27. Wadhwa, M.; Bakshi, M.P.S. Application of Waste-Derived Proteins in the Animal Feed Industry. In Protein Byproducts; Elsevier: Amsterdam, The Netherlands, 2016; pp. 161-192.

28. Applegate, T.J.; Troche, C.; Jiang, Z.; Johnson, T. The nutritional value of high-protein corn distillers dried grains for broiler chickens and its effect on nutrient excretion. Poult. Sci. 2009, 88, 354-359. [CrossRef] [PubMed]

29. Leytem, A.B.; Kwanyuen, P.; Thacker, P. Nutrient Excretion, Phosphorus Characterization, and Phosphorus Solubility in Excreta from Broiler Chicks Fed Diets Containing Graded Levels of Wheat Distillers Grains with Solubles. Poult. Sci. 2008, 87, $2505-2511$. [CrossRef] [PubMed]

30. Pahm, A.A.; Scherer, C.S.; Pettigrew, J.E.; Baker, D.H.; Parsons, C.M.; Stein, H.H. Standardized amino acid digestibility in cecectomized roosters and lysine bioavailability in chicks fed distillers dried grains with solubles. Poult. Sci. 2009, 88, 571-578. [CrossRef]

31. Webster, C.; Tidwell, J.H.; Goodgame, L.S.; Yancey, D.H.; Mackey, L. Use of soybean meal and distillers grains with solubles as partial or total replacement of fish meal in diets for channel catfish, Ictalurus punctatus. Aquaculture 1992, 106, 301-309. [CrossRef]

32. Webster, C.D.; Tidwell, J.H.; Goodgame, L.S.; Clark, J.A.; Yancey, D.H. Winter Feeding and Growth of Channel Catfish Fed Diets Containing Varying Percentages of Distillers Grains with Solubles as a Total Replacement of Fish Meal. J. Appl. Aquac. 1993, 1, 1-14. [CrossRef]

33. Li, M.; Oberle, D.; Lucas, P. Evaluation of corn distillers dried grains with solubles and brewers yeast in diets for channel catfish Ictalurus punctatus (Rafinesque). Aquac. Res. 2011, 42, 1424-1430. [CrossRef]

34. Hoffman, L.; Baker, A. Market Issues and Prospects for U.S. Distillers' Grains: Supply, Use, and Price Relationships; USDA: Washington, DC, USA, 2010.

35. Dickson, R.; Ryu, J.-H.; Liu, J.J. Optimal plant design for integrated biorefinery producing bioethanol and protein from Saccharina japonica: A superstructure-based approach. Energy 2018, 164, 1257-1270. [CrossRef]

36. Scholey, D.V.; Burton, E.J.; Williams, P.E.V. The bio refinery; producing feed and fuel from grain. Food Chem. 2016, 197, 937-942. [CrossRef] [PubMed]

37. Chipman, K. Ethanol-Maker's Sales Slump Shows Why It Wants to Ditch Biofuel. Available online: https:/ /www.bloomberg.com/ news/articles/2021-05-03/ethanol-maker-s-sales-slump-shows-why-it-wants-to-ditch-biofuel (accessed on 24 September 2021). 